\title{
Usable Science: Soil Health
}

\author{
By Justin D. Derner, Charles (Chuck) Stanley, and Chad Ellis
}

\section{On the Ground}

- Healthy soils are fundamental to sustainable rangelands, but soils function in obscurity. This is reflected in the belowground black-box mentality often attributed to soils.

- Transformational changes get the attention of land managers and the public for example, soil erosion associated with the Dust Bowl of the 1930s. This provides benchmarks for the context of importance in maintaining healthy soils for the productive capacity of rangelands.

- Benefits of soil health include enhanced soil waterholding capacity and appropriate nutrient cycling, which increases rangelands resilience to weather variability and predicted climate change.

- Future directions of usable science for soil health include: 1) characterization of soil health indicators for sensitivity levels that affect transitions/thresholds of state-and-transition models, 2) influences of management practices, predicted climate change, and extreme events, and 3) impact of prescribed fire and wildfires on soil health.

Keywords: infiltration, nutrient cycling, organic matter, productive capacity, resiliency, soil structure.

Rangelands 38(2):64-67

doi: 10.1016/j.rala.2015.10.010

(C) 2016 The Society for Range Management

oil functions in obscurity and is often underappreciated and taken for granted. That is, soil receives little press until it garners public attention when it is lost from lands due to wind and water erosion, or when mismanagement leads to degradation in productive capacity through loss of topsoil, organic matter, and/or changes in structural/chemical/biological attributes. Benchmark events such as the 1930s Dust Bowl remain entrenched in the memories of land managers for how drought can lead to widespread wind erosion (Fig. 1). Loss of soil due to water erosion (Fig. 2) can also be problematic on rangelands through reducing productivity and negatively impacting water quality. Soil erosion is expected to increase with predicted greater frequency of extreme rainfall events. ${ }^{1}$

\section{Obscurity of Soils}

The obscurity of soils was reflected in the prioritization of 142 issues identified from the workshop on Future Directions for Usable Science for Rangeland Sustainability held in Ardmore, OK, 2 June to 5 June 2014 (see Maczko et al. this issue). For the five topic groups discussed (water, animals, vegetation, socio-economics, and soils), only one soils issue was in the top 20\%: in 28th place-the last of the top 20\%-was the connection of soil health with state-and-transition model states in ecological site descriptions. A cluster of soils issues occupied rankings 50-52: 50) relevance of soil surveys to ecological site descriptions, 51) prescribed fire vs. wildfire effects on soils, and 52) targeting conservation programs/practices for soil resources on the post fire landscape. Of note, two soils issues were the lowest prioritized, with soil microbial designer communities ranking 141st, and dust and particulate matter ranking $142 \mathrm{nd}$.

\section{Why Soil Health is Important to Rangeland Sustainability?}

There is a tremendous interest, both from producers and the US Department of Agriculture (USDA), in augmenting the physical, chemical, and biological components of soil health with applicable conservation practices to increase production capacity and ecosystem services through enhanced soil water holding capacity, appropriate nutrient cycling, and greater resilience to weather variability and predicted climate changes. This interest, primarily driven by demonstrations of increased organic matter and soil structure in croplands through reduced tillage, no-till, and cover crops in mesic environments, has resulted in land managers expressing similar enthusiasm for soil health recovery on rangelands.

Primary relevant differences between soil health for croplands and rangelands include 1) intensive (e.g., maximizing inputs of capital and energy to maximize yields) management for crops vs. extensive (e.g., optimizing inputs of capital and energy to maintain and sustain yields) management for rangelands; 2) annual plants for crops vs. perennial plants in rangelands; and 3) croplands are mostly found in more mesic environments (along with improved pastures) with intrinsically higher soil quality, whereas rangelands are largely in more semiarid and arid environments that can restrict crop production. Even within the 


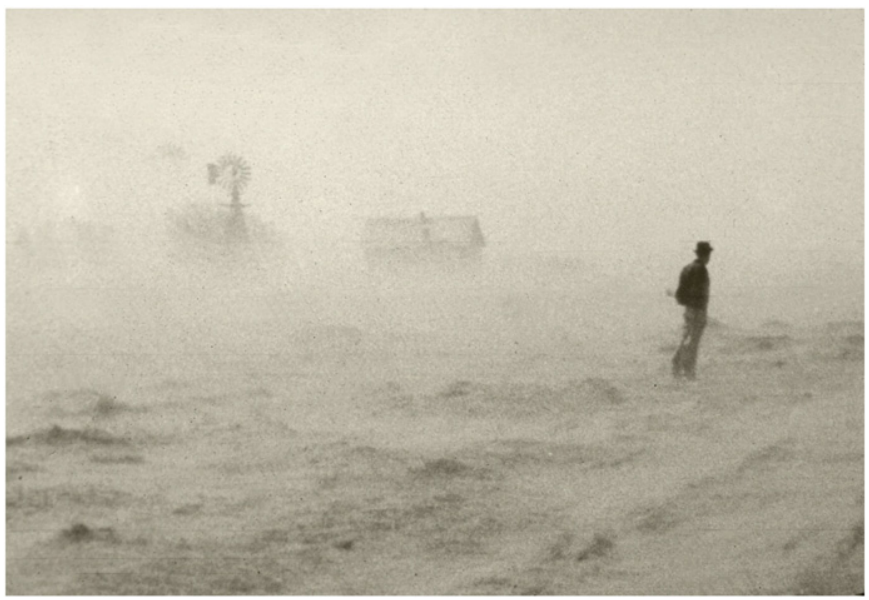

Figure 1. Wind erosion of soils from 1930s Dust Bowl (photo NRCSDC0100, courtesy of NRCS).

broad category of rangelands, these ecosystems are markedly different in terms of their soils and climate (exemplified by the mollisols of the Great Plains vs. the aridisols of the Great Basin), vegetation physiognomy (grasslands, shrublands, prairies, savannas), and evolutionary history (Great Plains with large migratory herbivore herds vs. Great Basin with small browsers). Together, these factors-classically defined as organisms (plants, animals, microbes), climate (growing season and precipitation), parent materials (geological substrates), and topography (slope and aspect) — establish a vast matrix of soil regions and individual sites that produce a variety of plant communities having a diversity of production potentials for ecosystem goods and services.

\section{Identification of Issues for Soil Health}

Three issues of usable science for soil health were identified during the Future Directions for Usable Science for Rangeland Sustainability Workshop:
1) characterization of soil health indicators for sensitivity levels that affect transitions/thresholds of state-and-transition models

2) influences of management practices, predicted climate change, and extreme events

3) the impact of prescribed fire and wildfires on soil health

We use these identified issues to frame the following sections of this article by addressing a key question for each of these issues.

\section{Question: How to Characterize Indicators of Soil Health for Sensitivity to Transitions/Thresholds of State-and-Transition Models?}

Differential responses to grazing, defined as ecological state changes, for rangelands are illustrated by the conversion of sagebrush shrublands in Nevada to monocultures of invasive annual grasses and the conversion of desert grasslands in New Mexico to sparse shrublands with high amounts of bare ground

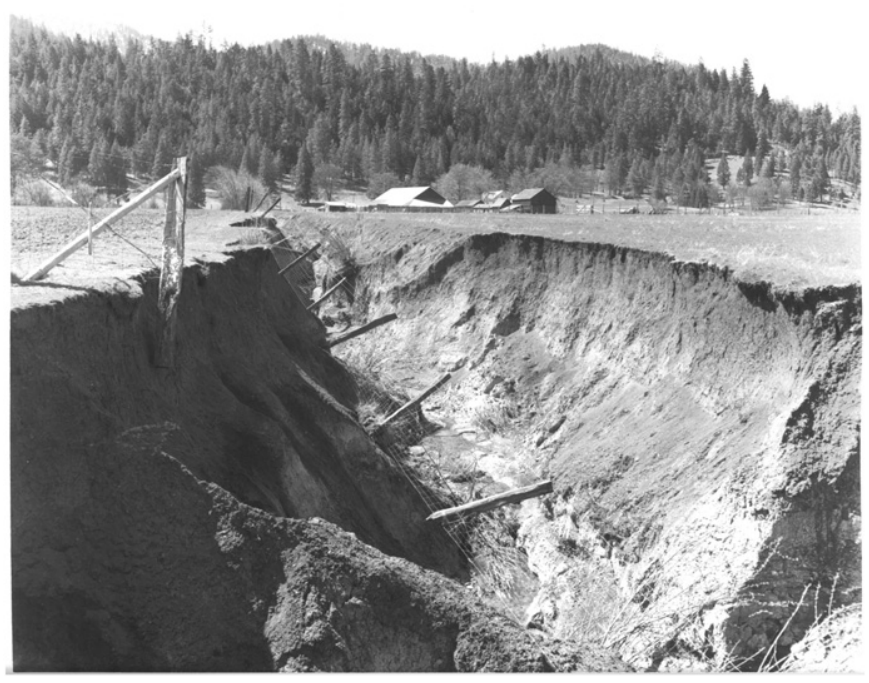

Figure 2. Water erosion of soils from California rangelands in 1952 (photo NRCSCA52085, courtesy of NRCS). 
cover. ${ }^{2}$ More subtle examples of vegetation change are exhibited across the Great Plains where a long evolutionary history of grazing by large herbivores (bison, elk, and now cattle) results in slow, gradual changes to vegetation even with substantial differences in stocking rates. For example, after 34 years of experimental season-long grazing, no discernable state change with heavy vs. light stocking in northern mixed-grass prairie was observed. ${ }^{3}$

Differences among rangeland ecosystems at the continental scale are often confounded at the local scale by the high degree of spatial heterogeneity of soils (landscape position, aspect, geological influences, historical/current erosion) and temporal variability of environmental factors, primarily precipitation in these water-limited systems (from droughts to downpours and deluges). Although this spatial and temporal diversity is common across intensively managed agricultural systems around the world, modern agronomic techniques have homogenized croplands and pasturelands with substantial capital and energy inputs through intensive management. For rangelands, however, there remains a key need to evaluate metrics of soil health for sensitivity as early warning indicators to determine transitions/thresholds in state-and-transition models. In transition-prone ecosystems with high resilience, these soil health-based indicators could be used to implement management changes to prevent undesirable transitions. ${ }^{2}$

\section{Question: What Are Influences of Management Practices, Predicted \\ Climate Change, and Extreme Events?}

Given that growing seasons in rangeland ecosystems are generally short (typically less than half a year), annual net primary productivity is low $(<1500 \mathrm{~kg} / \mathrm{ha}$ for most western rangelands, and much reduced in shrublands) and the product of management and environmental interactions dominate ecosystem processes, it is not surprising that low $(<1 \%)$ organic matter soils have sequestered equivalently low organic carbon as measured by the Bowen Ratio network of rangeland sites. ${ }^{4}$ Proper management focus on rangelands largely addresses conservation of existing soil resources and preventing degradation of these soil resources. Enhancing these soil resources can be long term, difficult, and challenging to measure. Whereas the effects of "poor" management are often reflected by degradation of soil resources, differentiating between "average" and "excellent" management impact on soil responses can be problematic given that discernable effects are often not readily apparent. Climatic limitations, including predicted changes in temperatures and precipitation as well as an increase in the frequency of extreme events ${ }^{1}$ in rangeland ecosystems can result in an attenuated productive capacity for many of these systems. This may preclude the use of input-driven management techniques and philosophies. As such, metrics of chemical, physical, and biological components of soil health will need to have very high accuracy and precision to effectively demonstrate realistic changes in these metrics attributable to conservation practices over time.
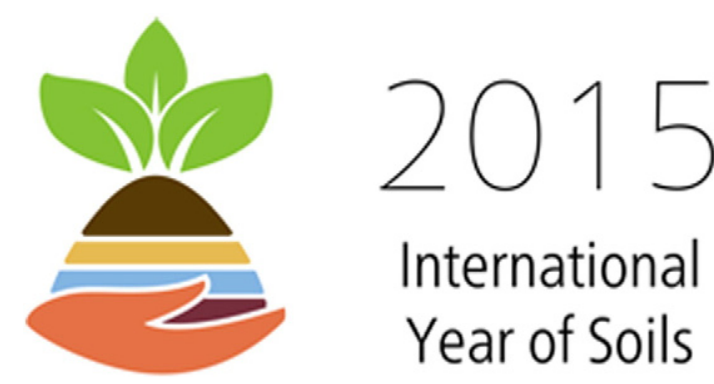

Figure 3. 2015 is the International Year of Soils.

\section{Question: How Is Soil Health Affected by Prescribed Fires and Wildfires?}

The responses of soils and hydrology to fire are highly variable, but water repellency (e.g., hydrophobic soil) and resulting runoff and soil erosion with greater sediment loads are negative effects of extreme soil heating that occurs mostly under intense wildfire where fire has been absent for many years or in ecosystems with less evolutionary importance of fire. ${ }^{5}$ A rangeland literature synthesis on prescribed fire as a conservation practice in the United States identified only 17 studies in which soil responses were addressed. ${ }^{5}$ Long-term seasonal prescribed fire treatments are available for assessments of soil health with winter and summer burns in the Edwards Plateau of Texas ${ }^{6}$ and spring and fall burns in shortgrass steppe of Colorado ${ }^{7}$.

Spatial patterns of soil biogeochemical resources are usually unaffected by burning, whether prescribed fires or single intense wildfire events. However, intense wildfires do affect small-scale (e.g., microsite) surface characteristics associated with hydrology, temperature, and erosion. ${ }^{8}$ Increasing frequency of wildfires could also alter the spatial pattern of soil biogeochemical resources. Moreover, more wildfires can influence landscape changes associated with runoff and soil erosion, largely mediated through plant compositional modifications such as conversion of sagebrush grassland to monocultures of invasive annual grasses in the Intermountain West.

\section{What Is the Future for Soil Health and Usable Science?}

While soils, and soil health, have often toiled in obscurity, two major events in 2015 represent a dramatic change in notoriety, making this a watershed year for soil in terms of press attention. First, the United Nations General Assembly declared 2015 as the International Year of the Soil (Fig. 3). Second, USDA Secretary Tom Vilsack announced on April 23, 2015, that Soil Health was among 10 USDA Building Blocks for Climate Smart Agriculture and Forest Strategy. ${ }^{i}$ As a result of these two key efforts, the future for soil health for usable science is quite promising for land managers, innovative producers, and climate-informed decision-making.

${ }^{\mathrm{i}}$ For more information on the USDA Building Blocks for Climate Smart Agriculture and Forest Strategy, see http://www.usda.gov/wps/portal/ usda/usdahome?contentidonly=true\&contentid=climate-smart.html. 
For example, utilizing novel experiments with adaptive grazing management ${ }^{\mathrm{ii}}$ wherein short "pulses" of grazing with a large herd followed by rest periods of more than 1 year provides experimental platforms to evaluate the efficacy of soil health monitoring efforts.

\section{Directions for Research: Soil Health and Usable Science?}

In discussions at the Future Directions for Usable Science for Rangeland Sustainability Workshop, after the identification of three issues of usable science for soil health, future research priority directions that would involve soil health and usable science were recognized. These research priority directions were distilled to four key questions that are relevant for land managers:

1) What are the effects of conservation practices (e.g., prescribed grazing, prescribed fire, and brush management) on the chemical, physical, and biological components of soil health?

2) Can the chemical, physical, and biological components of soil health be used as "early indicators" of phase, transition, and/or threshold shifts in plant communities for state-and-transition models to enhance ecological site descriptions?

3) How can the chemical, physical, and biological components of soil health be enhanced through adaptive management to increase the resilience of soils to weather variability and changing climate?

4) How can the tool kit to provide more robust and broad assessments of soil health and/or monitoring of the chemical, physical, and biological components for land managers in a timely and responsive manner to facilitate adaptive management be expanded?

\section{References}

1. Walsh, J., D. Wuebbles, K. Hayhoe, J. Kossin, K. Kunkel, G. Stephens, P. Thorne, R. Vose, M. Wehner, J. Willis, D. Anderson, S. Doney, R. Feely, P. Hennon, V. Kharin, T. Knutson, F. Landerer, T. Lenton, J. Kennedy, and R. SOMMERVILE. 2014. Our changing climate. In: Melillo JM, Richmond TC, \& Yohe GW, editors. Climate change impacts in the United States: the third national assessment. U.S. Global Change Research Program. p. 19-67. Available at: http://nca2014.globalchange.gov/ report\#section-1946. Accessed 3 May 2015.
2. Bestelmeyer, B.T., M.C. Duniway, D.K. James, L.M. Burkett, and K.M. Havstad. 2013. A test of critical thresholds and their indicators in a desertification-prone ecosystem: more resilience than we thought. Ecology Letters 16:339-345.

3. Porensky, L., K. Mueller, D. J. Augustine, and J. D. Derner. Thresholds and gradients in a semi-arid grassland: long-term grazing treatments induce slow, continuous and reversible vegetation change. Ecological Applications Article is in press. http://dx.doi.org/10.1111/1365-2664.12630.

4. Svejcar, T., R. Angel, J.A. Bradford, W. Dugas, W. Emmerich, A.B. Frank, T. Gilmanov, M. Haferkamp, D.A. Johnson, H. Mayeux, P. Mielnick, J.A. Morgan, N.Z. Saliendra, G.E. Schuman, P.L. Sims, and K. Snyder. 2008. Carbon fluxes on North American rangelands. Rangeland Ecology \& Management 61:465-474.

5. Fuhlendorf, S.D., R.F. Limb, D.M. Engle, and R.F. Miller. 2011. Assessment of prescribed fire as a conservation practice. In: $\&$ Briske DD, editor. Conservation benefits of rangeland practices: assessment, recommendations, and knowledge gaps. Available at: http:/www.nrcs.usda.gov/wps/portal/nrcs/detail/national/technical/nra/ceap/?\&cid=stelprdb1045811. Accessed 3 May 2015.

6. Taylor, C.A., D. Twidwell, N.E. Garza, C. Rosser, J.K. Hoffman, and T.D. Brooks. 2012. Long-term effects of fire, livestock herbivory removal and weather variability in Texas semiarid savanna. Rangeland Ecology \& Managemrnt 65:21-30.

7. Augustine, D.J., P. Brewer, D.M. Blumenthal, J.D. Derner, AND J.C. VON Fischer. 2014. Prescribed fire, soil inorganic nitrogen dynamics and plant responses in a semiarid grassland. Journal of Arid Environments 104:59-66.

8. Sankey, J.B., M.J. Germino, T.T. Sankey, and A.N. Hoover. 2012. Fire effects on the spatial pattern of soil properties in sagebrush steppe, USA: a meta-analysis. International Journal of Wildland Fire 21:545-556.

Authors are Supervisory Research Rangeland Management Specialist and Research Leader, USDA-Agricultural Research Service, Rangeland Resources Research Unit, Cheyenne, WY 82009 USA, Justin.Derner@ars.usda.gov (Derner); ${ }^{2}$ Rangeland Management Specialist, Grazing Lands Technology Team, USDA-Natural Resources Conservation Service, Central National Technology Support Center, Fort Worth, TX, 76115 USA (Stanley); ${ }^{3}$ Center Manager, Center for Land Stewardship, Noble Foundation, Ardmore, OK 73401 USA (Ellis).

\footnotetext{
ii For more information on this novel experiment, see http://www.ars. usda.gov/Main/Docs.htm?docid=24218.
} 